\title{
Bruxaria, Superstição e Cultura Popular na Primeira Visitação do Santo Ofício à América Portuguesa (1591-1595)
}

\author{
César Augusto Mendes Cruz (IC) e Prof. Dr. Rui Luis Rodrigues (Orientador)
}

\section{Resumo}

Com base nas confissões e denúncias da Primeira visita da Inquisição à América Portuguesa (1591-1595), nossa pesquisa quis compreender as receptividades e significações atribuídas à bruxaria, prática entranhada no cotidiano e na religiosidade popular da Colônia. No correr da pesquisa percebemos divergências entre aquilo que o Inquisidor classificou como um pecado supersticioso e a interpretação dos colonos, que não obstante as represálias da Igreja, praticavam e criam na eficácia de feitiços.

Palavras Chave: Inquisição, Bruxaria, Superstição.

\section{Introdução}

Encarregada de zelar pela ortodoxia religiosa dos súditos d'el Rei, a Inquisição Portuguesa (1536-1821) estendeu suas atividades às possessões lusitanas daquém mar pela primeira vez em 1591, data em que desembarcava na Bahia Frei Heitor Furtado de Mendonça. Canonista conimbricense e confessor de Filipe II, ao licenciado coube normatizar e vasculhar a religiosidade dos colonos, certificando-se de que heresias e divergências não acometessem o rebanho católico na recémocupada América. Dentre os desvios sob alçada do visitador estava a bruxaria, aquilo que tendeu a tratar como um pecado de consciência.

Neste tempo em que a Inquisição conheceu o nordeste brasileiro, quais os sentidos que a cultura popular e erudita atribuíram à Bruxaria? Qual o Sistema de pensamento e linguagem que fez do feitiço um malefício possível e credível? Por que a Inquisição, neste momento, foi aparentemente branda em punir os acusados que, como Maria Cajada, invocavam o auxílio de demônios para 'inclinar vontades', 'amansar maridos', adivinhar, causar impotências e malefícios a desafetos? Se houve ceticismo do visitador, por que os colonos insistiam em ir a sua mesa a denunciarem-se? Os valores culturais, os sistemas de significação que nutriam as crenças em fins do XVI constituíram nosso mote primordial de pesquisa.

\section{Resultados e Discussão}

O conceito de Superstição, segundo Clark (2006), foi central para o pensamento erudito da primeira modernidade. Embasada na teoria da magia natural de Tomás de Aquino, a Inquisição Portuguesa tendia a tratar a bruxaria como uma heresia menor, cuja eficácia estaria circunscrita à Ordem Natural imposta pelo Criador. Daí o ceticismo do visitador quanto à eficácia de pós, beberagens e cartas de tocar produzidos pelos acusados de feitiçaria.

Os colonos falavam de outra perspectiva de enunciação. A feitiçaria foi tratada por eles como uma realidade que afetava a sociabilidade e intervinha no cotidiano. Recorria-se às feiticeiras para estabelecer e reatar relações, desfazer compromissos anteriores, modificar o futuro, prever o futuro. Incômodas, elas forneciam subsídios para o lidar com as agruras do doloroso instaure da colônia.

\section{Conclusões}

Embora SOUZA (2009) tenha defendido o sincretismo como a marca da religiosidade brasileira, para o período estudado não notamos diferenças significativas entre as práticas mágicas denunciadas na Colônia e as delações recolhidas nos tribunais da Metrópole. O desfilar de acusações no nordeste se assemelha ao quadro recolhido por PAIVA (2002), sendo a mestiçagem cultural presente igualmente em Portugal.

\section{Agradecimentos}

Agradecemos o financiamento concedido pelo CnPq e SAE/UNICAMP, e ao Prof. Rui Rodrigues pela atenção e rigor, indispensáveis para a concretização desta pesquisa.

CLARK, Stuart. Pensando com Demônios: a ideia de Bruxaria no princípio da Europa Moderna. Tradução. São Paulo: EDUSP, 2006. PAIVA, José Pedro. Bruxaria e Superstição num Pais sem caça às bruxas (1600-1774). 2ª edição. Lisboa: Notícias, 2002. SOUZA, Laura de Mello e. O Diabo e a Terra de Santa Cruz: feitiçaria e religiosidade popular no Brasil Colonial. $2^{\mathrm{a}}$ edição. São Paulo: Cia das Letras, 2009. 